\section{Sources of Resistance for Two Differentially Pathogenic Strains of Xanthomonas fragariae in Fragaria Genotypes}

\author{
John L. Maas ${ }^{1}$, Cristina Gouin-Behe ${ }^{2}$, John S. Hartung ${ }^{1}$, and \\ Stan C. Hokanson ${ }^{3}$ \\ Fruit Laboratory, U.S. Department of Agriculture, Agricultural Research \\ Service, Beltsville, MD 20705
}

Additional index words. strawberry, bacterial angular leafspot, disease resistance

\begin{abstract}
Bacterial angular leafspot disease (BALD) of strawberry (Fragaria sp. and $\boldsymbol{F}$. xananassa Duchesne cultivars) has become increasingly destructive to strawberry fruit and plant production in Canada and the United States, as well as in other countries. The disease, caused by Xanthomonas fragariae Kennedy and King, was first documented in Minnesota in 1960, and has become of worldwide concern because of the economic impact of BALD in strawberry fruit and nursery-plant production and the lack of adequate disease control strategies. We tested 81 Fragaria genotypes, including representatives of $F$. Xananassa, $F$. chiloensis (L.) Duchesne, $F$. virginiana Duchesne, and $F$. vesca $L$., for resistance to two pathogenic strains of $X$. fragariae. Two genotypes, a native $F$. virginiana from Minnesota and an $F$. virginiana $\times F$. $\times$ ananass $a$ hybrid, were found to resist infection by both bacterial strains and may be potential sources of resistance to other strains of $X$. fragariae.
\end{abstract}

Bacterial angular leafspot of strawberry, first documented from Minnesota in 1960, was determined to be caused by the bacterium Xanthomonas fragariae (Kennedy and King, 1962a). Since 1962, angular leafspot has occurred in many strawberry-growing areas of North America, Europe, South America, Africa, and Australasia (Maas et al., 1995). The European Plant Protection Organization (EPPO) lists $X$. fragariae as an important quarantine pest (Smith et al., 1992) and has prescribed phytosanitary procedures (Calzolari, 1994). The Food and Agriculture Organization of the United Nations and the International Plant Genetic Resources Institute also lists angular leafspot as a potential risk in international distribution of strawberry germplasm (Diekmann et al., 1994).

Strawberry cultivars reportedly vary in susceptibility to angular leafspot. Howard (1971) reported that 'Dabreak' was more severely affected than 'Florida 90', 'Missionary', 'Tioga', 'Torrey', 'Salinas', and La. 1158, and that damage to 'Florida 90' was minimal and infection of 'Missionary' very light. Of 64

\footnotetext{
Received for publication 12 Apr. 1999. Accepted for publication 3 Aug. 1999. This work was funded in part by a USDA-ARS Germplasm Evaluation Grant. The cost of publishing this paper was defrayed in part by the payment of page charges. Under postal regulations, this paper therefore must be hereby marked advertisement solely to indicate this fact.

${ }^{1}$ Research Plant Pathologist.

E-mail: jmaas@asrr.arsusda.gov;

jhartung@asrr.arsusda.gov

${ }^{2}$ Scientific Research Assistant.

E-mail: cbehe@asrr.arsusda.gov

${ }^{3}$ Research Geneticist.

E-mail: hokanson@asrr.arsusda.gov
}

polymerase chain reaction (PCR), repetitive extragenic palindromic (REP) PCR, and random amplified polymorphic DNA (RAPD) PCR analyses. Pooler et al. (1996) recognized four ERIC PCR groups in X. fragariae but also concluded that $X$. fragariae strains from various locations around the world are genetically fairly homogeneous. Tests for differential pathogenicities among the strains were not included in these analyses.

Our objectives were to evaluate a large number of native North American clones of Fragaria species and $F$. Xananassa cultivars for resistance to strains of Xanthomonas fragariae representative of two ERIC PCR groups, with primary focus on octoploid species because of their potential for rapid assimilation of resistance into strawberry breeding programs.

\section{Materials and Methods}

Two strains of $X$. fragariae were used in these studies: ATCC 33239 (American Type Culture Collection, Rockville, Md.), the type strain of $X$. fragariae from Minnesota, and strain Xf-3 from North Carolina (D. Ritchie, North Carolina State Univ., Raleigh). Both strains are pathogenic to strawberry (Milholland et al., 1996; Pooler et al., 1996).

Strains of $X$. fragariae were stored in $15 \%$ glycerol gel in culture tubes at $-70{ }^{\circ} \mathrm{C}$ until used for inoculum preparation (Roberts et al., 1996). Strains were seeded onto solid sucrose peptone agar (SPA) medium (Hayward, 1960) and incubated at $24{ }^{\circ} \mathrm{C}$ for $3 \mathrm{~d}$. Bacteria were washed from culture plates with sterile distilled water and the suspensions were diluted to a final optical density of 0.100 at $\mathrm{OD}_{595}$, corresponding to $\approx 10^{8}$ colony-forming units/ $\mathrm{mL}$.

Strawberry plants were obtained from several germplasm collections in North America (Table 1) and propagated in a quarantine greenhouse facility away from other strawberry plants. Plants were watered prior to inoculation and leaves to be inoculated were identified with tape placed on their petioles. Generally, the two youngest, fully expanded leaves on each of two plants per genotype were selected per $X$. fragariae strain. Bacterial suspensions were drawn into a $3-\mathrm{mL}$ syringe, the needle was removed, the syringe aperture placed firmly against the abaxial surface of a leaflet, and the syringe plunger carefully depressed until a water-soaked area became visible (Fig. 1). Care was taken not to injure the leaflet with pressure from the syringe body. In all tests, each leaflet was inoculated at four sites away from the midrib for a total of 12 inoculations per leaf, resulting in 24 inoculation sites per plant on each of two plants per genotype. Inoculated plants were placed in individual clear plastic bags for $3 \mathrm{~d}$ in a lighted laboratory at room temperature. Plants then were moved to a mist bench where they were misted for $1 \mathrm{~min}$, three times per hour. After 1 week in the mist bench, plants were moved to benches in a shaded greenhouse at $\approx 24^{\circ} \mathrm{C}$ with a 16-h photoperiod (natural plus supplemental overhead lighting). Plants were watered and 
Table 1. Strawberry genotype reactions to infection by two strains (ATCC 33239 and Xf-3) of Xanthomonas fragariae in Tests 1, 2, and 3, and an overall rating.

\begin{tabular}{|c|c|c|c|c|c|c|c|}
\hline \multirow[b]{3}{*}{$\begin{array}{l}\text { Fragaria species, clone } \\
\text { and origin }\end{array}$} & \multicolumn{7}{|c|}{ Disease reaction $^{y}$} \\
\hline & \multicolumn{2}{|c|}{ Test 1} & \multicolumn{2}{|c|}{ Test 2} & \multicolumn{2}{|c|}{ Test 3} & \multirow[b]{2}{*}{$\begin{array}{l}\text { Overal } \\
\text { rating }\end{array}$} \\
\hline & $\begin{array}{l}\text { ATCC } \\
33239\end{array}$ & $\mathrm{Xf}-3$ & $\begin{array}{l}\text { ATCC } \\
33239\end{array}$ & $\mathrm{Xf}-3$ & $\begin{array}{l}\text { ATCC } \\
33239\end{array}$ & $\mathrm{Xf}-3$ & \\
\hline \multicolumn{8}{|l|}{ F. Xananassa } \\
\hline Blakemore (Md.) & $\mathrm{r}$ & $\mathrm{s}$ & $\mathrm{s}$ & $\mathrm{s}$ & $\mathrm{s}$ & $\mathrm{s}$ & $\mathrm{S}$ \\
\hline Cesena (Italy) & $\mathrm{s}$ & $\mathrm{s}$ & & & & & $\mathrm{S}$ \\
\hline Delmarvel (Md.) & $\mathrm{r}$ & $\mathrm{r}$ & $\mathrm{s}$ & $\mathrm{r}$ & $\mathrm{s}$ & $\mathrm{s}$ & S \\
\hline Earliglow (Md.) & $\mathrm{s}$ & $\mathrm{s}$ & $\mathrm{s}$ & $\mathrm{s}$ & & & $\mathrm{S}$ \\
\hline Gilbert (Wisc.) & $\mathrm{s}$ & $\mathrm{s}$ & & & & & $\mathrm{S}$ \\
\hline Guardian (Md.) & $\mathrm{s}$ & $\mathrm{s}$ & $\mathrm{s}$ & $\mathrm{s}$ & & & $\mathrm{S}$ \\
\hline Lateglow (Md.) & $\mathrm{r}$ & $\mathrm{r}$ & $\mathrm{s}$ & $\mathrm{r}$ & & & S/R \\
\hline Marmolada (Italy) & $\mathrm{s}$ & $\mathrm{s}$ & $\mathrm{s}$ & $\mathrm{s}$ & & & $\mathrm{S}$ \\
\hline Mohawk (Md.) & $\mathrm{r}$ & $\mathrm{r}$ & $\mathrm{s}$ & $\mathrm{r}$ & & & $\mathrm{S} / \mathrm{R}$ \\
\hline Puget Reliance (Wash.) & $\mathrm{s}$ & $\mathrm{s}$ & & & & & $\mathrm{S}$ \\
\hline Scott (Md.) & $\mathrm{s}$ & $\mathrm{r}$ & $\mathrm{s}$ & $\mathrm{s}$ & & & $\mathrm{S}$ \\
\hline Soquel (Calif.) & $\mathrm{s}$ & $\mathrm{s}$ & & & & & $\mathrm{S}$ \\
\hline Sweet Charlie (Fla.) & $\mathrm{s}$ & $\mathrm{r}$ & $\mathrm{s}$ & $\mathrm{r}$ & $\mathrm{s}$ & $\mathrm{s}$ & $\mathrm{S}$ \\
\hline Torrey (Calif.) & $\mathrm{s}$ & $\mathrm{s}$ & & & & & $\mathrm{S}$ \\
\hline Winona (Minn.) & s & $\mathrm{r}$ & $\mathrm{s}$ & $\mathrm{r}$ & & & $\mathrm{S} / \mathrm{R}$ \\
\hline MD-683 (Md.) & $--^{x}$ & $\mathrm{r}$ & $\mathrm{s}$ & $\mathrm{s}$ & & & $\mathrm{S}$ \\
\hline SG5 (Plateau) (Tenn.) & $\mathrm{s}$ & $\mathrm{s}$ & $\mathrm{s}$ & $\mathrm{s}$ & & & $\mathrm{S}$ \\
\hline 61-16-99 (Calif.) & $\mathrm{s}$ & $\mathrm{r}$ & $\mathrm{s}$ & $\mathrm{r}$ & & & $\mathrm{S} / \mathrm{R}$ \\
\hline \multicolumn{8}{|l|}{$F . \times$ ananassa $\times F$. virginiana ${ }^{\mathrm{w}}$} \\
\hline 80-4-38 (Md.) & $\mathrm{r}$ & $\mathrm{r}$ & --- & --- & $\mathrm{r}$ & $\mathrm{r}$ & $\mathrm{R}$ \\
\hline \multicolumn{8}{|l|}{ F. chiloensis } \\
\hline CA 11 (Ore.) & s & $\mathrm{s}$ & $\mathrm{s}$ & s & & & S \\
\hline CA 12 (Ore.) & $\mathrm{r}$ & $\mathrm{r}$ & $\mathrm{s}$ & $\mathrm{s}$ & $\mathrm{s}$ & $\mathrm{s}$ & $\mathrm{S}$ \\
\hline CCCA (Calif.) & $\mathrm{r}$ & $\mathrm{r}$ & $\mathrm{s}$ & $\mathrm{s}$ & $\mathrm{s}$ & $\mathrm{s}$ & $\mathrm{S}$ \\
\hline Del Norte (Calif.) & $\mathrm{s}$ & $\mathrm{r}$ & $\mathrm{s}$ & $\mathrm{s}$ & $\mathrm{s}$ & $\mathrm{s}$ & $\mathrm{S}$ \\
\hline FRA 0590 (B.C.) & $\mathrm{r}$ & --- & $\mathrm{s}$ & $\mathrm{s}$ & $\mathrm{s}$ & $\mathrm{s}$ & S \\
\hline FRA 0711 (B.C.) & $\mathrm{s}$ & $\mathrm{s}$ & $\mathrm{s}$ & $\mathrm{s}$ & & & $\mathrm{S}$ \\
\hline FRA 0808 (B.C.) & $\mathrm{s}$ & $\mathrm{s}$ & $\mathrm{s}$ & $\mathrm{s}$ & & & S \\
\hline Lon3E (Chile) & $\mathrm{s}$ & $\mathrm{s}$ & $\mathrm{s}$ & $\mathrm{s}$ & & & $\mathrm{S}$ \\
\hline M-03 (Ore.) & s & $\mathrm{s}$ & $\mathrm{s}$ & $\mathrm{s}$ & & & S \\
\hline P-11 (Ore.) & $\mathrm{s}$ & $\mathrm{s}$ & $\mathrm{s}$ & $\mathrm{s}$ & & & $\mathrm{S}$ \\
\hline Y-56 (Ore.) & $\mathrm{s}$ & $\mathrm{s}$ & $\mathrm{s}$ & $\mathrm{s}$ & & & $\mathrm{S}$ \\
\hline F. virginiana & & & & & & & \\
\hline AC 8118 (Md.) & $\mathrm{s}$ & $\mathrm{s}$ & $\mathrm{s}$ & $\mathrm{s}$ & & & $\mathrm{S}$ \\
\hline K89-5 (N.S.) & $\mathrm{s}$ & $\mathrm{r}$ & $\mathrm{s}$ & $\mathrm{r}$ & $\mathrm{s}$ & $\mathrm{s}$ & $\mathrm{S}$ \\
\hline K89-6 (N.S.) & --- & --- & $\mathrm{s}$ & $\mathrm{s}$ & $\mathrm{s}$ & $\mathrm{s}$ & $\mathrm{S}$ \\
\hline K92-19 (N.S.) & $\mathrm{s}$ & $\mathrm{s}$ & $\mathrm{s}$ & $\mathrm{s}$ & & & $\mathrm{S}$ \\
\hline RH01 (Minn.) & $\mathrm{s}$ & $\mathrm{s}$ & $\mathrm{s}$ & $\mathrm{s}$ & & & S \\
\hline RH02 (Alaska) & $\mathrm{s}$ & $\mathrm{s}$ & $\mathrm{s}$ & $\mathrm{s}$ & & & $\mathrm{S}$ \\
\hline RH03 (N.Y.) & $\mathrm{s}$ & $\mathrm{s}$ & $\mathrm{s}$ & $\mathrm{s}$ & & & S \\
\hline RH04 (Minn.) & $\mathrm{r}$ & $\mathrm{r}$ & $\mathrm{s}$ & $\mathrm{s}$ & $\mathrm{s}$ & $\mathrm{s}$ & $\mathrm{S}$ \\
\hline RH05 (N.Y.) & $\mathrm{s}$ & $\mathrm{s}$ & $\mathrm{s}$ & $\mathrm{s}$ & & & $S$ \\
\hline RH06 (Minn.) & $\mathrm{s}$ & $\mathrm{s}$ & $\mathrm{s}$ & $\mathrm{s}$ & & & $\mathrm{S}$ \\
\hline RH07 (N.Y.) & $\mathrm{r}$ & $\mathrm{s}$ & $\mathrm{s}$ & $\mathrm{s}$ & & & S \\
\hline RH09 (Minn.) & $\mathrm{s}$ & $\mathrm{s}$ & & & & & S \\
\hline RH10 (Minn.) & s & $\mathrm{s}$ & $\mathrm{s}$ & $\mathrm{s}$ & & & $S$ \\
\hline RH11 (Minn.) & $\mathrm{s}$ & $\mathrm{s}$ & $\mathrm{s}$ & $\mathrm{s}$ & & & $\mathrm{S}$ \\
\hline RH12 (Minn.) & s & $\mathrm{r}$ & s & $\mathrm{s}$ & $\mathrm{s}$ & $\mathrm{s}$ & $\mathrm{S}$ \\
\hline RH13 (Minn.) & $\mathrm{s}$ & --- & $\mathrm{s}$ & --- & $\mathrm{s}$ & $\mathrm{s}$ & $\mathrm{S}$ \\
\hline RH14 (Minn.) & $\mathrm{r}$ & $\mathrm{r}$ & s & $\mathrm{s}$ & & & S \\
\hline RH15 (Minn.) & s & s & $\mathrm{s}$ & $\mathrm{s}$ & & & S \\
\hline RH16 (N.Y.) & s & $\mathrm{s}$ & $\mathrm{s}$ & $\mathrm{s}$ & & & S \\
\hline RH17 (Minn.) & $\mathrm{s}$ & $\mathrm{r}$ & $\mathrm{s}$ & $\mathrm{s}$ & & & $\mathrm{S}$ \\
\hline RH18 (N.Y.) & s & $\mathrm{s}$ & $\mathrm{s}$ & $\mathrm{s}$ & & & S \\
\hline RH20 (Minn.) & $\mathrm{s}$ & $\mathrm{s}$ & $\mathrm{s}$ & $\mathrm{s}$ & & & $\mathrm{S}$ \\
\hline RH21 (Minn.) & s & $\mathrm{s}$ & s & $\mathrm{s}$ & & & S \\
\hline RH22 (Minn.) & s & $\mathrm{s}$ & $\mathrm{s}$ & $\mathrm{s}$ & & & S \\
\hline RH25 (Ore.) & s & $\mathrm{s}$ & $\mathrm{s}$ & $\mathrm{s}$ & & & S \\
\hline RH30 (Minn.) & $\mathrm{s}$ & $\mathrm{s}$ & $\mathrm{s}$ & $\mathrm{s}$ & & & $\mathrm{S}$ \\
\hline RH32 (N.Y.) & s & $\mathrm{s}$ & s & $\mathrm{s}$ & & & S \\
\hline RH34 (N.Y.) & $\mathrm{r}$ & $\mathrm{r}$ & $\mathrm{s}$ & $\mathrm{r}$ & $\mathrm{s}$ & $\mathrm{s}$ & $\mathrm{S}$ \\
\hline RH35 (N.Y.) & --- & $\mathrm{s}$ & $\mathrm{s}$ & $\mathrm{r}$ & $\mathrm{s}$ & $\mathrm{s}$ & S \\
\hline RH37 (Minn.) & $\mathrm{s}$ & $\mathrm{s}$ & s & s & & & $\mathrm{S}$ \\
\hline RH38 (Minn.) & $\mathrm{s}$ & $\mathrm{s}$ & & & & & $\mathrm{S}$ \\
\hline RH39 (Minn.) & $\mathrm{s}$ & $\mathrm{s}$ & $\mathrm{s}$ & $\mathrm{s}$ & & & $\mathrm{S}$ \\
\hline RH41 (Minn.) & $\mathrm{s}$ & $\mathrm{s}$ & $\mathrm{s}$ & $\mathrm{s}$ & & & S \\
\hline RH42 (Minn.) & s & $\mathrm{r}$ & $\mathrm{s}$ & $\mathrm{s}$ & & & $\mathrm{S}$ \\
\hline RH44 (Minn.) & $\mathrm{r}$ & $\mathrm{s}$ & $\mathrm{s}$ & $\mathrm{s}$ & & & S \\
\hline
\end{tabular}

fertilized as needed. Pesticides were applied to plants as necessary to control insects and mites. Inoculation sites were evaluated at the end of the first week and once a week thereafter for 4 weeks. In the initial screening (Test 1), plants were considered susceptible (s) on a whole-plant basis if bacterial exudate ("slime") was produced at any inoculation site (Fig. 2), if inoculation sites remained translucent, or if secondary infection sites were apparent on inoculated leaves (Fig. 3 A and B). Plants were considered resistant $(r)$ if inoculation sites lost translucency and/or developed necrotic centers that did not progress beyond inoculation sites (Fig. $3 \mathrm{C}$ and D). Genotypes showing questionable reactions or that appeared resistant were tested in at least one more inoculation series (Tests 2 and 3) (Table 1). Genotypes appearing to be resistant to strain Xf-3 but susceptible to strain ATCC 33239 after two or three tests were not included in the final test (Test 4) of those genotypes considered resistant to both strains (Table 2).

In the final test (Test 4), genotypes appearing resistant $(\mathrm{R})$ to both $X$. fragariae strains in the previous series were inoculated and maintained as above. Inoculation sites were evaluated and rated using the following criteria: $0=$ no reaction, transient water-soaking from inoculation no longer evident; 1 = transient water-soaking evident in the inoculation site; $2=$ slight chlorosis or necrosis in the center of the inoculation site; 3 = water-soaking expanding beyond inoculation site and often bacterial exudate evident (Fig. 2); $4=$ necrosis spreading beyond the inoculation site (Fig. $3 \mathrm{~A}$ ) and/or secondary infections evident (Fig. 3B); and $5=$ total necrosis of the inoculation area and leaflet changing color from chlorotic yellow to reddish-brown. Plants were considered resistant if inoculation sites lost translucency and/or developed necrotic centers that did not progress beyond inoculation sites (Fig. $3 \mathrm{C}$ and D); all other reactions were considered to be evidence of susceptibility (S). At the conclusion of the test, inoculation sites were cut from leaves, surface sterilized, fragmented, placed in sterile water for $10 \mathrm{~min}$, and agitated on a vortex mixer for 5-10 s. A bacterial transfer loop was used to streak the extract onto SPA medium in culture plates. Plates were incubated at room temperature for development of colonies typical of $X$. fragariae (Roberts et al., 1996). Ratings were converted by angular transformation prior to mean separation by Duncan's multiple range test.

\section{Results and Discussion}

Of the 81 genotypes tested against two virulent strains of $X$. fragariae in Tests 1,2 , and 3, only two, 80-4-38 and SG-89, were resistant to both strains (Table 1). Several genotypes ('Lateglow', 'Mohawk', 'Winona', 61-16-99, RH47, SG-11, SG-15, SG-22, SG24 , and SG-25) were resistant to $X$. fragariae Xf-3 but not to strain ATCC 33239. No genotypes were both susceptible to strain Xf-3 and resistant to strain ATCC 33239. Resistance was not observed in any $F$. chiloensis genotypes; however, our sample size for $F$. 
Table 1. Continued.

\begin{tabular}{|c|c|c|c|c|c|c|c|}
\hline \multirow[b]{3}{*}{$\begin{array}{l}\text { Fragaria species, clone } \\
\text { and origin }^{2}\end{array}$} & \multicolumn{7}{|c|}{ Disease reaction $^{y}$} \\
\hline & \multicolumn{2}{|c|}{ Test 1} & \multicolumn{2}{|c|}{ Test 2} & \multicolumn{2}{|c|}{ Test 3} & \multirow[b]{2}{*}{$\begin{array}{l}\text { Overall } \\
\text { rating }\end{array}$} \\
\hline & $\begin{array}{l}\text { ATCC } \\
33239\end{array}$ & Xf-3 & $\begin{array}{l}\text { ATCC } \\
33239\end{array}$ & Xf-3 & $\begin{array}{l}\text { ATCC } \\
33239\end{array}$ & $\mathrm{Xf}-3$ & \\
\hline RH46 (Alta.) & $\mathrm{s}$ & $\mathrm{s}$ & $\mathrm{S}$ & $\mathrm{s}$ & & & $\mathrm{S}$ \\
\hline RH47 (Minn.) & $\mathrm{s}$ & $\mathrm{r}$ & s & $\mathrm{r}$ & & & $\mathrm{S} / \mathrm{R}$ \\
\hline RH48 (Minn.) & --- & --- & s & $\mathrm{r}$ & s & $\mathrm{s}$ & $\mathrm{S}$ \\
\hline SG-2 (Ark.) & $\mathrm{s}$ & $\mathrm{r}$ & $\mathrm{s}$ & s & & & $\mathrm{S}$ \\
\hline SG-3 (Ark.) & s & --- & s & s & & & $\mathrm{S}$ \\
\hline SG-4 (N.C.) & $\mathrm{s}$ & $\mathrm{s}$ & $\mathrm{s}$ & s & & & $\mathrm{S}$ \\
\hline SG-9 (Pa.) & s & $\mathrm{r}$ & $\mathrm{s}$ & $\mathrm{s}$ & & & $\mathrm{S}$ \\
\hline SG-11 (Pa.) & $\mathrm{s}$ & $\mathrm{r}$ & $\mathrm{s}$ & $\mathrm{r}$ & & & $\mathrm{S} / \mathrm{R}$ \\
\hline SG-21 (Pa.) & $\mathrm{s}$ & $\mathrm{r}$ & $\mathrm{s}$ & s & & & S \\
\hline SG-22 (Pa.) & s & $\mathrm{r}$ & s & $\mathrm{r}$ & & & $\mathrm{S} / \mathrm{R}$ \\
\hline SG-24 (Pa.) & s & $\mathrm{r}$ & s & $\mathrm{r}$ & & & $\mathrm{S} / \mathrm{R}$ \\
\hline SG-82 (N.C.) & $\mathrm{r}$ & $\mathrm{r}$ & s & $\mathrm{s}$ & s & $\mathrm{s}$ & $\mathrm{S}$ \\
\hline SG-89 (Minn.) & s & $\mathrm{r}$ & $\mathrm{r}$ & $\mathrm{r}$ & $\mathrm{r}$ & $\mathrm{r}$ & $\mathrm{R}$ \\
\hline \multicolumn{8}{|l|}{$F$. vesca } \\
\hline SG-15 (Pa.) & s & $\mathrm{r}$ & $\mathrm{s}$ & $\mathrm{r}$ & & & $\mathrm{S} / \mathrm{R}$ \\
\hline SG-25 (Pa.) & s & $\mathrm{r}$ & --- & --- & & & $\mathrm{S} / \mathrm{R}$ \\
\hline Tozahizic (Mexico) & $\mathrm{s}$ & $\mathrm{s}$ & $\mathrm{s}$ & $\mathrm{s}$ & & & $\mathrm{S}$ \\
\hline
\end{tabular}

${ }^{\mathrm{z}} \mathrm{F}$. $\times$ ananassa cultivars, MD-683, 80-4-38, AC 8118, Del Norte, CCA, Tozahizic, and SG numbers from the USDA Beltsville Fruit Laboratory collection; 61-16-99 from C. Winterbottom, Univ. of California, Davis. F. chiloensis FRA numbered clones from the National Clonal Germplasm Repository, Trenton, Ont., and the remainder from S. Cameron and C. Shanks, Washington State Univ., Vancouver. F. virginiana K numbered clones from A. Jamieson, Agriculture and Agri-Food Canada, Kentville, N.S., RH numbered clones from J. Luby, Univ. of Minnesota, St. Paul.

"Clones rated susceptible (" $\mathrm{s}$ " in individual tests or " $\mathrm{S}$ " overall) or resistant (" $\mathrm{r}$ " in individual tests or "R" overall).

${ }^{\mathrm{x}}$ Clone not included in this test series.

w'Earliglow' x SG-26 (F. virginiana).

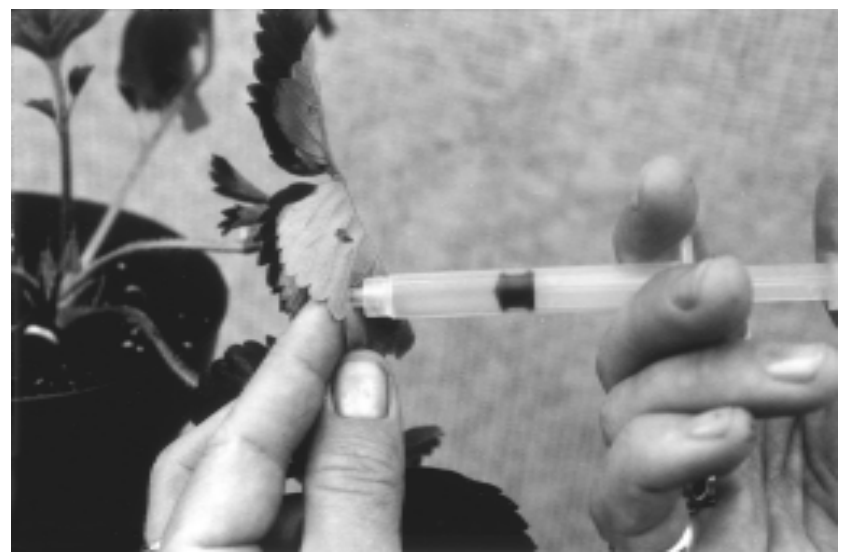

Fig. 1. Inoculation of strawberry leaflets with a small syringe, containing a suspension of Xanthomonas fragariae, that is gently pressed against the abaxial leaf surface and the plunger gently depressed until a water-soaked area becomes visible.

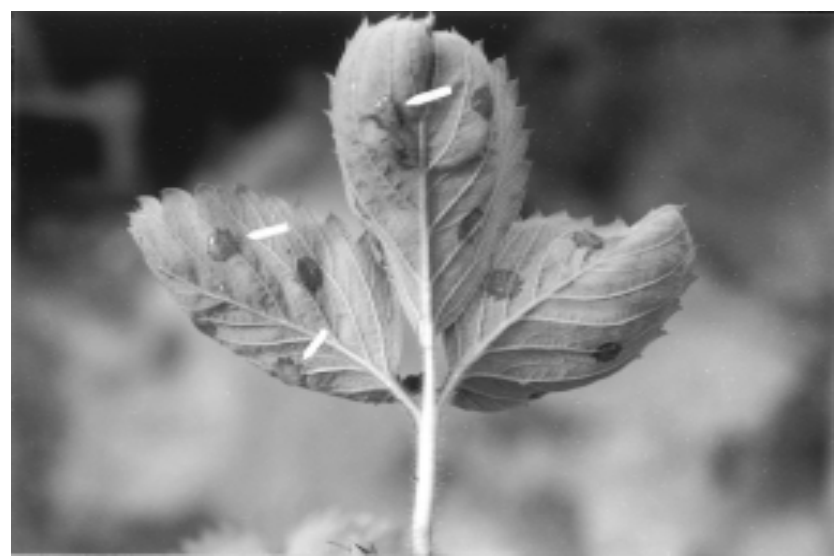

Fig. 2. Strawberry leaflets of a susceptible genotype ('Gilbert') inoculated with Xanthomonas fragariae, showing bacterial angular leafspot symptoms with bacterial exudate (pointers) on several inoculation sites. chiloensis may have been too small to include possible resistant genotypes. To confirm the resistance of 80-4-38 and SG-89, a fourth test against the two $X$. fragariae strains was performed, and both genotypes were again rated resistant (Table 2). The expression of resistance appeared to be a general reaction to infection by $X$. fragariae in that the inoculated sites, although appearing chlorotic (Fig. 3C), lost translucency, exhibited no bacterial exudate or lesion expansion, and sometimes separated from normal leaf tissue (Fig. 3D).

The ultimate source of resistance to $X$. fragariae in octoploid Fragaria is not apparent. However, based on the widely dispersed origins of the resistant genotypes in this study, resistance may be widely distributed among North American F. virginiana. Clone 80-4-38 ['Earliglow' $x$ F. virginiana clone SG-26 (PI 414129)] was selected at Beltsville (J.L.M.) in a study of resistance to fruit rots caused by Botrytis cinerea Pers.:Fr. and Colletotrichum $\mathrm{sp}$. The other doubly resistant genotype in this study, clone SG-89 (Luby no. MS 7-7), collected by M. Stahler in 1986 from Pine County, Minn. $\left(46^{\circ} 00^{\prime} \mathrm{N}, 92^{\circ} 45^{\prime} \mathrm{W}\right)$, appears typical of Minnesota populations in terms of morphology and runnering and flowering responses ( $\mathrm{J}$. Luby, pers. comm.).

Although clones 80-4-38 and SG-89 could potentially be useful in breeding programs for incorporating resistance to BALD, it would be advantageous to understand the mode of transmission of resistance imparted by 80-4-38 and SG-89, and whether resistance to all of the four ERIC PCR groups of $X$. fragariae identified by Pooler et al. (1996) would result. Note that several genotypes also carry with them some negative traits; for example, susceptibility to other important diseases (genotypes 6116-99 and 80-4-38), small fruit size ( $F$. virginiana genotypes), and resistance to only one strain (Xf-3) of $X$. fragariae ( $F$. Xananassa cultivars). Nevertheless, we conclude that genotypes 80-4-38 and SG-89 would be exceptionally good candidates for inclusion as parents in a breeding program concerned with developing new cultivars resistant to the bacterial angular leafspot disease.

\section{Literature Cited}

Calzolari, A. 1994. Xanthomonas fragariae: Detection methods in strawberry plants. OEPP/ EPPO Bul. 24:343-346.

Diekmann, M., E.A. Frison, and T. Putter. 1994. Strawberry angular leaf spot. FAO/IPGRI Technical guidelines for the safe movement of strawberry germplasm. Food and Agr. Organization of the United Nations, Rome/Intl. Plant Genetics Resources Inst., Rome. p. 35-36.

Hayward, A.C. 1960. A method for characterizing Pseudomonas solanacearum. Nature 186:405406.

Hazel, W.J. 1981. Xanthomonas fragariae, cause of strawberry angular leafspot: Its growth, symptomatology, bacteriophages, and control. $\mathrm{PhD}$ Diss., Univ. of Maryland, College Park.

Hazel, W.J. and E.L. Civerolo. 1980. Procedures for growth and inoculation of Xanthomonas fragariae, causal organism of angular leaf spot of strawberry. Plant Dis. 64:178-181.

Howard, C.M. 1971. Occurrence of strawberry an- 


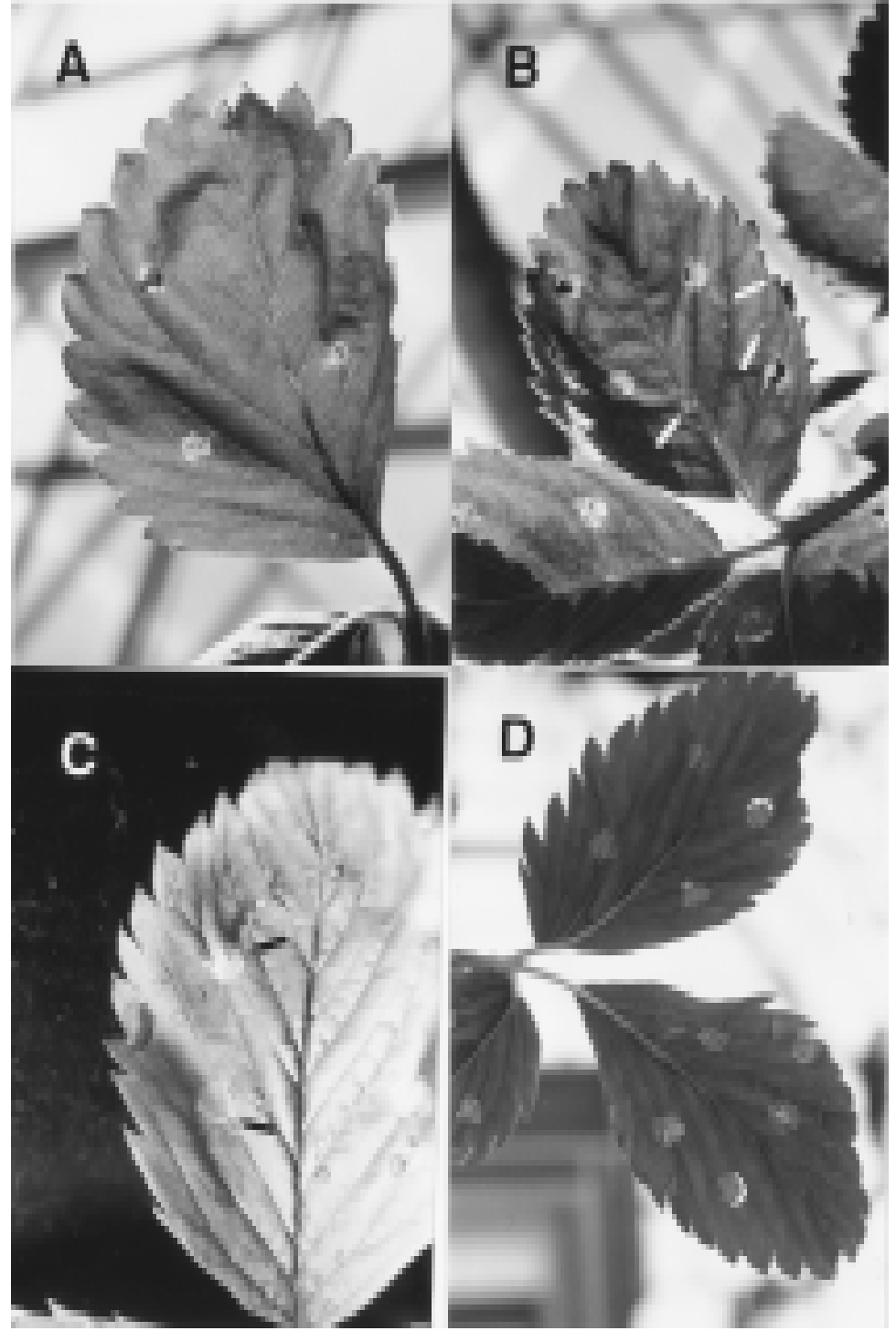

Fig. 3. Strawberry leaflets inoculated with Xanthomonas fragariae showing (A) bacterial angular leafspot symptoms on a susceptible genotype ('Gilbert') with translucent and angular appearance of lesions, (B) secondary lesions (pointers) developing in the susceptible genotype, $(\mathbf{C})$ lack of translucency at inoculation sites (pointers) in the resistant genotype SG-89, and (D) dislocation of inoculated tissue from noninoculated tissue in the resistant genotype 80-4-38.

Table 2. Mean angular leafspot symptom ratings ${ }^{z}$ of strawberry genotypes inoculated with two strains of Xanthomonas fragariae in Test 4.

\begin{tabular}{lllccr}
\hline & & \multicolumn{4}{c}{ Days after inoculation } \\
\cline { 3 - 6 } Strain & Genotype & 7 & 14 & 23 & 37 \\
\hline Xf3 & $80-4-38$ & $1.0^{\mathrm{y}}$ & $1.0 \mathrm{a}^{\mathrm{y}}$ & $1.0 \mathrm{a}$ & $1.5 \mathrm{a}$ \\
& SG-89 & 1.0 & $1.0 \mathrm{a}$ & $1.0 \mathrm{a}$ & $1.5 \mathrm{a}$ \\
& Delmarvel & 1.0 & $1.0 \mathrm{a}$ & $1.5 \mathrm{a}$ & $3.5 \mathrm{~b}$ \\
& Gilbert & 1.0 & $3.0 \mathrm{~b}$ & $4.0 \mathrm{~b}$ & $5.0 \mathrm{~b}$ \\
ATCC 33239 & NS & & & \\
& 80-4-38 & 1.0 & $1.0 \mathrm{a}$ & $1.0 \mathrm{a}$ & $1.0 \mathrm{a}$ \\
& SG-89 & 1.0 & $2.0 \mathrm{a}$ & $2.0 \mathrm{a}$ & $2.0 \mathrm{a}$ \\
& Delmarvel & 1.5 & $1.5 \mathrm{a}$ & $1.5 \mathrm{a}$ & $4.0 \mathrm{~b}$ \\
& Gilbert & 1.5 & $3.0 \mathrm{~b}$ & $5.0 \mathrm{~b}$ & $5.0 \mathrm{c}$ \\
& & & & \\
\hline
\end{tabular}

${ }^{2}$ Mean separation within columns and isolates by Duncan's multiple range test, $P \leq 0.05$; NS $=$ nonsignificant Ratings were converted by angular transformation for analysis.

${ }^{y}$ Mean ratings of two plants inoculated at four locations on each leaflet of two leaves per plant, resulting in 24 inoculation sites per plant. Ratings based on the following criteria: $0=$ no reaction, transient watersoaking from inoculation no longer evident; 1 = transient water-soaking evident in the inoculation site; $2=$ slight chlorosis or necrosis in the center of the inoculation site; 3 = water-soaking expanding beyond inoculation site; 4 = necrosis spreading beyond the inoculation site and/or secondary infections evident; and $5=$ total necrosis of the inoculation area and leaflet changing color from chlorotic to reddish-brown. Ratings were converted by angular transformation prior to means separation in columns within strains by Duncan's multiple range test. gular leaf spot, Xanthomonas fragariae, in Florida. Plant Dis. Rpt. 55:142.

Kennedy, B.W. and T.H. King. 1962a. Angular leaf spot of strawberry caused by Xanthomonas fragariae sp. nov. Phytopathology 52:873-875.

Kennedy, B.W. and T.H. King. 1962b. Studies on epidemiology of bacterial angular leafspot on strawberry. Plant Dis. Rpt. 46:360-363.

Luby, J.J., J.F. Hancock, and J.S. Cameron. 1991. Expansion of the strawberry germplasm base in North America, p. 66-75. In: A. Dale and J. Luby (eds.). The strawberry into the 21 st century. Timber Press, Portland, Ore.

Maas, J.L., M.R. Pooler, and G.J. Galletta. 1995. Bacterial angular leafspot disease of strawberry: Present status and prospects for control. Adv. Strawberry Res. 14:18-24.

Milholland, R.D., D.F. Ritchie, M.E. Daykin, and W.A. Gutierrez. 1996. Multiplication and translocation of Xanthomonas fragariae in strawberry. Adv. Strawberry Res. 15:13-17.

Pooler, M.R., D.F. Ritchie, and J.S. Hartung. 1996. Genetic relationships among strains of Xanthomonas fragariae based on random amplified polymorphic DNA PCR, repetitive extragenic palindromic PCR, and enterobacterial repetitive intergenic consensus PCR data and generation of multiplexed PCR primers useful for the identification of this pathogen. Appl. Environ. Microbiol. 62:3121-3127.

Roberts, P.D., J.B. Jones, C.K. Chandler, R.E. Stall, and R.D. Berger. 1996. Survival of Xanthomonas fragariae on strawberry in summer nurseries in Florida detected by specific primers and nested polymerase chain reaction. Plant Dis. 80:12831288.

Sjulin, T.M. and A. Dale. 1987. Genetic diversity of North American strawberry cultivars. J. Amer. Soc. Hort. Sci. 112:375-385.

Smith, I.M., D.G. McNamara, P.R. Scott, and K.M. Harris (eds.). 1992. Xanthomonas fragariae, p. 829-833. In: Quarantine pests for Europe. Data sheets on European Communities and for the European and Mediterranean Plant Protection Organization. CAB Intl., Wallingford, Oxon, U.K. 